\title{
Caracterização molecular e fenotípica de estirpes de Escherichia coli produtoras de shiga-toxina (STEC) não-O157 de fezes e carcaças bovinas
}

\author{
[Molecular and phenotypic characterization of shiga toxin producing Escherichia coli (STEC) non-O157 \\ strains from bovine feces and carcass]
}

\author{
A.F. Carvalho, S. Miyashiro, A.F.C. Nassar, A. Noda, D.T. Gabriel, L. Baldassi \\ Instituto Biológico - Centro de Pesquisa e Desenvolvimento de Sanidade Animal - São Paulo, SP
}

\begin{abstract}
RESUMO
Foram coletados 100 suabes retais e 100 suabes de carcaças bovinas em matadouros do estado de São Paulo, e um total de 326 estirpes de E. coli foram identificadas, sendo 163 de amostras retais e 163 de amostras de carcaça. Todos os isolados submetidos à PCR para detecção dos genes das toxinas Stx1 e Stx2 foram identificados como não-O157 e fenotipados pelo teste da citotoxicidade em células Vero. Das 26 estirpes que apresentaram apenas o gene $s t x l$, das 56 que apresentaram apenas o gene stx2 e das 30 estirpes que apresentaram ambos os genes, $17(65,4 \%), 42(75 \%)$ e $22(73,3 \%)$, respectivamente, foram positivas ao teste de citotoxicidade. Não houve diferença estatística entre os três perfis genéticos e na positividade ao teste de citotoxicidade. Os resultados mostram a alta frequência de expressão dos fatores de virulência das STEC de bovinos.
\end{abstract}

Palavras-chave: bovino, Escherichia coli, STEC, fezes, carcaça

\begin{abstract}
In the present study 100 rectal and 100 carcass swabs were collected from bovines at slaughterhouses in São Paulo state, and the total of 326 E. coli strains were identified (163 from rectal samples and 163 from carcass samples). All the isolates were submitted to PCR for Stxl and Stx 2 toxin gene detection and all strains were identified as non-O157 and phenotyped by the citotoxicity test in Vero cells. Out of 26 strains that presented only the stx1 gene, 56 that presented only the stx2 gene and 30 that presented both genes, 17 (65.4\%), 42 (75\%) and 22 (73.3\%), respectively, were positive for the citotoxicity test. There was no statistically significant difference among these three toxinotyping profiles and positivity in the citotoxicity test, but the results show high frequency of virulence factor expression of bovine.
\end{abstract}

Keywords: bovine, Escherichia coli, STEC, feces, carcass

\section{INTRODUÇÃO}

Os principais fatores de virulência da Escherichia coli produtora de shiga-toxina (STEC) são proteínas citotóxicas ativas em células Vero (Konowalchuk et al., 1977). STEC são os principais patógenos de origem alimentar associados à gastroenterite em humanos, causando desde diarreia a complicações, como colite hemorrágica e síndrome hemolíticourêmica (Karmali, 1989; Ojo et al., 2010). Ruminantes domésticos, especialmente bovinos e ovinos, são portadores assintomáticos, destacando-se como os principais reservatórios de STEC que causam infecções em humanos (Blanco et al., 2003; Ojo et al., 2010).

A transmissão de STEC ocorre mediante o consumo de carnes cruas ou malcozidas, produtos laticínios não pasteurizados, vegetais e água contaminados. Ruminantes selvagens também são considerados potencial fonte de infecção para o homem (Blanco et al., 2003). Segundo Moreira et al. (2003), regiões com alta prevalência de STEC em bovinos, normalmente, têm altas taxas de infecções humanas associadas à Escherichia coli produtora de shiga-toxina.

Recebido em 1 de março de 2012

Aceito em 1 de agosto de 2012

E-mail: linebio@gmail.com 
As STEC produzem dois tipos de toxina, Stx1 e Stx2, codificadas por fagos temperados que estão íntegros no cromossomo da E. coli (Strockbine et al., 1986). Essas estirpes também podem expressar a proteína intimina, codificada pelo gene eae, que constitui outro fator de virulência responsável pela aderência e destruição do epitélio intestinal. Estirpes de STEC que carreiam os genes stxl, stx2 e eae estão associadas com as doenças humanas mais severas (Shaw et al., 2004), sendo que o gene stx2 compreende 11 variantes distintas e é considerado $\mathrm{o}$ fator de virulência mais importante das STEC associado a doenças humanas (Brett et al., 2002).

Métodos tradicionais para identificação de STEC em amostras de fezes envolvem cultivos de enriquecimento, seleção das colônias bacterianas, análise bioquímica dos isolados e determinação dos principais marcadores de virulência, tais como as shiga-toxinas. Essa metodologia é laboriosa, demorada e requer vários dias para a identificação dos microrganismos (Osek, 2002). A reação de PCR tem sido considerada a metodologia mais sensível para determinação da presença das STEC em amostras fecais ou de alimentos (Paton e Paton, 1998), mesmo para detecção de E. coli $\mathrm{O} 157$ e outros sorogrupos (Osek, 2002).

A maioria dos estudos, até o momento, tem se concentrado na pesquisa de STEC sorovar O157:H7, porém têm sido frequentemente observadas infecções humanas por STEC sorogrupo não-O157 (Menrath et al., 2010). Deste modo, o presente estudo teve o objetivo de estudar a ocorrência de Escherichia coli nãoO157 produtora de shiga-toxina (STEC) em intestinos e carcaças de bovinos saudáveis levados ao abate em matadouro do estado de São Paulo, bem como comparar suas características fenotípica e molecular.

\section{MATERIAL E MÉTODOS}

Durante o período de um ano, foram colhidos pareadamente 100 suabes retais e 100 suabes das carcaças bovinas em matadouro do estado de São Paulo. Os suabes foram imediatamente colocados em tubos contendo caldo de infusão cérebrocoração (BHI; Difco) e levados ao laboratório para análise dentro de até 24 horas em caixa de isopor contendo gelo reciclável. As suspensões foram semeadas em placas de ágar Levine EMB (Difco) e incubadas a $37^{\circ} \mathrm{C}$ por $18-24$ horas em aerobiose. De acordo com a quantidade de UFCs com características de $E$. coli isoladas na amostra, foram selecionadas aleatoriamente até três colônias suspeitas (enegrecidas com brilho verde-metálico) por amostra e confirmadas por testes bioquímicos: triple sugar iron (TSI), citrato e produção de indol (Koneman, 2008).

Para observação da presença e do tipo de hemólise apresentada, todas as estirpes de E. coli foram semeadas em ágar Mueller-Hinton (Difco) acrescido de $5 \%$ de sangue desfibrinado de carneiro, e incubadas a $37^{\circ} \mathrm{C}$ por 24 horas em aerobiose.

Para detecção dos genes produtores da shigatoxina, as estirpes de E. coli foram submetidas à reação de Multiplex-PCR com primers descritos por Paton e Paton (1998), identificando os genes stxl e stx2 que amplificam fragmentos de 180 e 255 pares de bases (pb), respectivamente. A amplificação de DNA foi realizada num volume total de $50 \mu \mathrm{L}$ contendo $10 \mathrm{mM}$ de Tris $\mathrm{Hcl} \mathrm{pH}$ $9,0,3 \mathrm{mM}$ de $\mathrm{MgCl}_{2}, 200 \mu \mathrm{M}$ de cada desoxirribonucleotídeo, 20pmol de cada primer $($ stx $1 F$, stx $1 R$, stx $2 F$ e stx $2 R)$, três unidades de Taq DNA polimerase e $10 \mu \mathrm{L}$ de DNA. Anteriormente ao ciclo de temperaturas para amplificação do DNA, foi utilizada desnaturação inicial a $95^{\circ} \mathrm{C}$ por 10 minutos e, ao final, extensão a $72^{\circ} \mathrm{C}$ por 10 minutos. A amplificação compreendeu 30 ciclos de desnaturação a $94^{\circ} \mathrm{C}$ por 60 segundos, hibridização a $59^{\circ} \mathrm{C}$ por 60 segundos e extensão a $72^{\circ} \mathrm{C}$ por 30 segundos.

Para detecção das estirpes não-O157, foi realizada a PCR utilizando-se os primers O157F e O157R descritos por Paton e Paton (1998), os quais amplificam fragmentos de $259 \mathrm{pb}$ referentes à porção da região de $r f b$ que codifica antígeno $\mathrm{O}$ de E. coli O157. Para a amplificação, foram utilizados $10 \mathrm{mM}$ de Tris $\mathrm{HCl} \mathrm{pH} 9,0$, 1,5mM de $\mathrm{MgCl} 2,200 \mathrm{mM}$ de cada nucleotídeo (dNTPs), 200 $\mu \mathrm{M}$ de cada dNTP, 30pmol de cada primer $(\mathrm{O} 157 \mathrm{~F}$ e O157R), 1,5 unidade de Taq DNA polimerase e $10 \mu \mathrm{L}$ de DNA. Anteriormente ao ciclo de temperaturas para amplificação do DNA, foi utilizada desnaturação inicial a $95^{\circ} \mathrm{C}$ por 10 minutos e, ao final, extensão a $72^{\circ} \mathrm{C}$ por 10 minutos. A amplificação compreendeu 30 ciclos de desnaturação a $94^{\circ} \mathrm{C}$ por 60 segundos, hibridização a $59^{\circ} \mathrm{C}$ por 60 
segundos e extensão a $72^{\circ} \mathrm{C}$ por 30 segundos. Como controle positivo das reações, foram utilizadas estirpes STEC (stxl e stx2 positivas) não-O157, isoladas no laboratório de Bacteriologia Geral do Instituto Biológico de São Paulo.

As amplificações foram realizadas em termociclador Peltier Thermal Cycler-100 (MJ Research), e a análise dos produtos amplificados foi feita por eletroforese em gel de agarose a $1,3 \%$, corado com brometo de etídeo $(0,5 \mu \mathrm{g} / \mathrm{mL})$ e, posteriormente, fotografado sob luz ultravioleta $(300-320 \mathrm{~nm})$ pelo sistema de fotodocumentação Câmera Kodak Digital DC/120 Zoom, com o software 1D Image Analysis (Kodak Digital Science).

Para detecção da produção de toxinas em células Vero, os isolados de E. coli foram incubados overnight a $37^{\circ} \mathrm{C}$ em caldo tripticase de soja (Difco) com homogeneização a 250rpm e centrifugados a $18000 \mathrm{~g}$ por 20 minutos a $4^{\circ} \mathrm{C}$. Os sobrenadantes foram filtrados com filtros estéreis $0,45 \mu \mathrm{m}$ (Sartorius) e, então, utilizados para preparar diluições seriadas na base 2 (1:4 a 1:16) em meio mínimo essencial (MEM), e $50 \mu \mathrm{L}$ de cada diluição foram inoculados em $100 \mu \mathrm{L}$ de monocamadas confluentes de células Vero cultivadas em microplacas de 96 orifícios. As placas foram incubadas a $37^{\circ} \mathrm{C}$ em atmosfera com $5 \%$ de $\mathrm{CO}_{2}$, e as mudanças morfológicas nas células foram observadas após 24 e 48 horas de incubação, por microscópio invertido com contraste de fase. Foram consideradas positivas as estirpes que produziram efeito citotóxico a partir da diluição 1:8.

\section{RESULTADOS}

A partir de 78/100 (78\%) dos suabes retais e $77 / 100(77 \%)$ dos suabes de carcaças, foram isoladas 326 estirpes de E. coli, sendo 163 (50\%) de origem retal e 163 (50\%) de carcaça.

Das E. coli identificadas, foi possível detectar a presença dos genes das toxinas por meio da PCR, num total de 112/326 (34,4\%) estirpes provenientes de $42 / 78(53,8 \%)$ suabes retais e de $27 / 77(35,1 \%)$ suabes de carcaça. Dessas, 26/112 $(23,2 \%)$ estirpes continham o gene stxl; 56/112 (50\%) continham o gene stx2; e 30/112 (26,8\%) continham ambos os genes (Fig. 1).

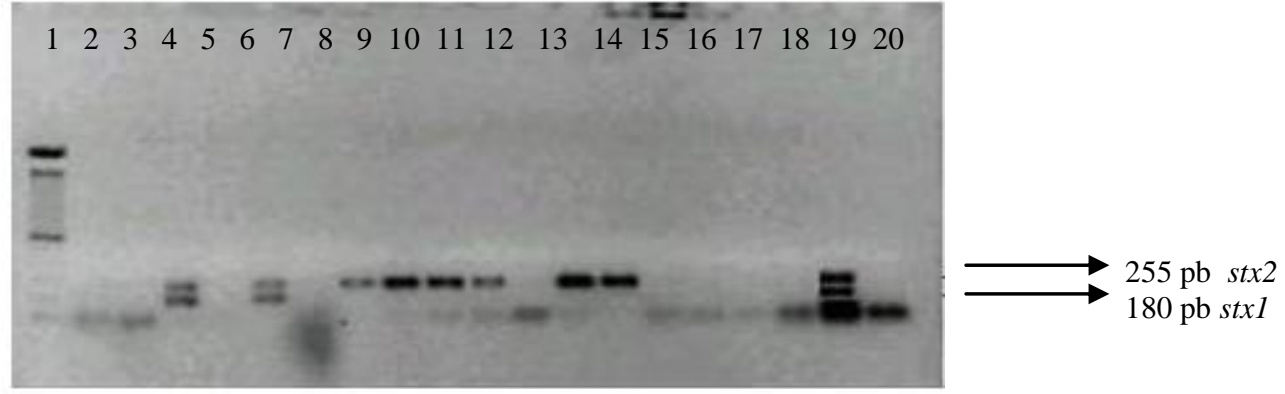

Figura 1. Resultados obtidos na amplificação por Multiplex-PCR para detecção dos genes stx1 e stx2 nas estirpes de E. coli. 1: Marcador de peso molecular (100 bp DNA Ladder - Invitrogem); 2-18: estirpes de E. coli isoladas; 19: controle positivo; 20: controle negativo.

Todas as estirpes (112/112 - 100\%) que continham pelo menos um dos genes da shigatoxina foram identificadas como STEC nãoO157 por meio da PCR; portanto, todas as STEC foram avaliadas quanto ao teste de citotoxicidade em células Vero.
Foram positivas ao teste de citotoxicidade 17/26 $(65,4 \%)$ estirpes que apresentavam apenas o gene stx $1 ; 42 / 56(75 \%)$ que apresentavam apenas o gene stx2; e 22/30 (73,3\%) que apresentavam ambos os genes, totalizando 81/112 (72,3\%) estirpes em que foi observado efeito citopático nas diluições maiores ou iguais a 1:8 (Tab. 1). 
Tabela 1. Resultados do teste de citotoxicidade em células Vero das estirpes STEC não-O157

\begin{tabular}{ccccc}
\hline PCR & stxl+/stx $2-$ & stx $1-/$ st $x 2+$ & stx $1+/$ stx $2+$ & Total \\
\hline Citotoxicidade & 17 & 42 & 22 & 81 \\
\hline+ & 9 & 14 & 8 & 31 \\
- & 26 & 56 & 30 & 112 \\
\hline
\end{tabular}

Das estirpes de E. coli identificadas, 233/326 $(71,5 \%)$ não apresentaram hemólise; 87/326 $(26,7 \%)$ apresentaram $\beta$-hemólise; 4/326 (1,2\%) apresentaram $\alpha$-hemólise; e 2/326 (0,6\%) apresentaram dupla hemólise no cultivo em ágar Mueller-Hinton acrescido de 5\% de sangue desfibrinado de carneiro. Das estirpes que continham pelo menos um dos genes da shigatoxina, observou-se que $82 / 112(73,2 \%)$ não apresentavam hemólise; 29/112 (25,9\%) apresentavam $\beta$-hemólise; nenhuma (0\%) apresentou $\alpha$-hemólise; e $1 / 112 \quad(0,9 \%)$ apresentou dupla hemólise (Tab. 2).

Tabela 2. Presença de hemólise em ágar sangue Mueller-Hinton das estirpes de E. coli com relação à detecção dos genes stxl e stx2

\begin{tabular}{cccc}
\hline Hemólise & stx $1-/$ stx $2-$ & stx $1+\mathrm{e} / \mathrm{ou}$ stx $2+$ & Total \\
\hline Ausência & 151 & 82 & 233 \\
$\beta$ & 58 & 29 & 87 \\
$\alpha$ & 4 & 0 & 4 \\
Dupla & 1 & 1 & 2 \\
Total & 214 & 112 & 326 \\
\hline
\end{tabular}

\section{DISCUSSÃO}

As STEC são uma importante causa de doenças gastrointestinais, particularmente no homem, já que tais infecções podem resultar em sequelas, como síndrome hemolítico-urêmica (SUH) e púrpura trombótica trombocitopênica. A morbidade e a mortalidade associadas com surtos recentes de doença por STEC têm alertado sobre o risco deste microrganismo para a saúde pública. Por esta razão, há uma demanda crescente por procedimentos diagnósticos melhores para detecção de STEC em materiais fecais e, em particular, em alimentos como carnes e produtos lácteos (Paton e Paton, 1998). A lista completa de determinantes de virulência necessários para que as STEC causem a SUH não é conhecida, entretanto as shiga-toxinas são um fator-chave na patogênese da doença. A presença do gene eae não está inteiramente ligada à patogenicidade no homem, e estirpes não-O157 sem esse gene têm sido associadas a surtos e casos esporádicos da doença em humanos (Paton et al., 1999; Feng et al., 2001).
No presente estudo, foram isoladas 163 estirpes de $E$. coli a partir de 78/100 (78\%) suabes retais e 163 estirpes de E. coli a partir de 77/100 (77\%) suabes de carcaça, sendo que todas foram identificadas como não-O157. Nas 326 estirpes de $E$. coli isoladas, foi pesquisada a presença dos genes stxl e stx 2 por PCR, observando-se ausência de ambos na maioria: 214/326 (65,6\%), tanto em estirpes provenientes do reto quanto da carcaça. A presença de pelo menos um dos dois genes stx pesquisados teve distribuição estatisticamente significante de acordo com a origem da amostra $\left(\chi^{2}=9,195 ; \mathrm{P}=0,002\right)$, tendo sido detectado stxl e/ou stx2 em 69/163 (42,3\%) estirpes isoladas a partir dos suabes retais e $43 / 163(26,4 \%)$ das estirpes isoladas dos suabes de carcaças.

$\mathrm{Na}$ avaliação da citotoxicidade em cultura de células Vero, foram positivas 17/26 $(65,4 \%)$ das estirpes que continham apenas o gene stxl; 42/56 $(75 \%)$ das estirpes que continham apenas o gene stx2; e 22/30 (73,3\%) das estirpes que continham ambos os genes, não havendo diferença significante entre estes três perfis obtidos na 
PCR e a positividade no teste de citotoxicidade $\left(\chi^{2}=0,952 ; \mathrm{P}=0,621\right)$.

Independentemente da presença de um dos genes st $x$ ou de ambos, a maioria das estirpes expressou as toxinas, portanto, a detecção desses genes pela técnica da PCR pode ser um importante indicativo do potencial patogênico de E. coli. No presente estudo, não houve uma relação entre a presença dos genes stx e a produção de hemólise no meio de ágar Mueller-Hinton acrescido de 5\% de sangue desfibrinado de carneiro $\left(\chi^{2}=0,242\right.$; $\mathrm{P}=0,489)$, diferentemente do verificado por Moon (1974), que afirmou que geralmente $E$. coli patogênicas são hemolíticas $(90 \%)$. No entanto, o mesmo autor encontrou $29 \%$ de estirpes que não continham nenhum dos genes pesquisados e que apresentaram hemólise no ágar sangue, dados semelhantes ao do presente estudo, onde 29,4\% (63/214) das estirpes que não apresentavam os genes stx, eram hemolíticas.

As STEC são descritas como agentes causadores de diarreia e disenteria em bovinos, porém altas frequências de STEC também são observadas em bovinos não diarreicos (Leomil et al., 2003). Neste estudo, observou-se o isolamento de STEC em amostras de animais saudáveis, sendo que a presença apenas do gene stx2, que é considerado o fator de virulência mais importante associado a doenças humanas, foi predominante nas estirpes provenientes das amostras fecais de bovinos $(50 \%)$.

No Brasil, Irino et al. (2005) pesquisaram a ocorrência de STEC em 153 amostras fecais de bovinos saudáveis provenientes de fazendas leiteiras do estado de São Paulo, sendo detectadas 220 estirpes STEC por PCR, das quais apenas $3 \%$ continham o gene stxl, 40,6\% o gene st $x 2$ e $56,4 \%$ continham ambos os genes. Leomil et al. (2003) pesquisaram a ocorrência de STEC em 344 amostras fecais, sendo 205 provenientes de bovinos saudáveis e 139 de bovinos com diarreia, coletadas em fazendas de gado do estado de São Paulo, onde foram detectadas 44 estirpes STEC por PCR, sendo que $12(50 \%)$ foram positivas para o gene stxl, quatro $(16,7 \%)$ para o gene stx2 e oito $(33,3 \%)$ para ambos os genes. Além destes, foram realizados outros estudos em diferentes partes do mundo envolvendo as STEC (Zweifel et al., 2005; Lefebvre et al., 2009; Ojo et al., 2010), os quais mostraram a existência de variações no perfil da presença dos genes stxl e stx 2 dependendo do tipo e da origem das amostras analisadas. No presente estudo, dentre as STEC isoladas a partir de amostras bovinas, foi observada maior frequência de estirpes com apenas o gene stx2 (56/112), porém $72,3 \%$ (81/112) das STEC expressaram as verotoxinas independentemente da presença de um ou de ambos os genes.

Bovinos e ovinos são os reservatórios primários de STEC, mas essas têm sido isoladas também em cavalos, cães e pássaros. As STEC são transmitidas ao homem mediante o consumo de alimentos contaminados, como carnes cruas ou malcozidas e leite não pasteurizado. O homem também pode se infectar com STEC pela ingestão de vegetais, frutas e água contaminados, ou pelo contato direto com fezes infectadas.

A sorotipagem das STEC é insuficiente para determinar as propriedades patogênicas das estirpes, pois tais microrganismos são muito variáveis no repertório dos determinantes de virulência. Portanto, análises dos genótipos de estirpes de STEC pelo uso de sondas genéticas específicas ou PCR, promovem informações mais detalhadas sobre a variabilidade genética e os subtipos.

\section{CONCLUSÕES}

Os resultados apresentados reforçam o fato de que os bovinos são reservatórios de STEC e podem transmitir esse patógeno ao homem, tanto por contato direto com animais portadores como pela manipulação e ingestão de produtos cárneos contaminados, visto que foi comprovada a presença de STEC com plena atividade da shigatoxina em amostras de carcaças bovinas, sendo necessária a adoção de medidas efetivas para a prevenção da contaminação de produtos animais destinados ao consumo humano. 


\section{REFERÊNCIAS}

BLANCO, J.; BLANCO, M.; BLANCO, J.E. et al.Verotoxin-producing Escherichia coli in Spain: prevalence, serotypes, and virulence genes of $\mathrm{O} 157: \mathrm{H} 7$ and non-O157 VTEC in ruminants, raw beef products, and humans. Exp. Bio. Med., v.228, p.345-351, 2003.

BRETT, K.N.; HORNITZKY, M.A.; BETTELHEIM, K.A. et al. Bovine non-O157 Shiga toxin 2-containing Escherichia coli isolates commonly possess Stx2-EDL933 and/or Stx2vhb subtypes. J. Clin. Microbiol., v.41, p.2716-2722, 2002.

FENG, P.; WEAGANT, S.D.; MONDAY, S.R. Genetic analysis for virulence factors in Escherichia coli O104:H21 that was implicated in an outbreak of hemorrhagic colitis. J. Clin. Microbiol., v.39, p.24-28, 2001.

IRINO, K.; KATO, M.A.M.F.; VAZ, T.M.I. et al. Serotypes and virulence markers of Shiga toxin-producing Escherichia coli (STEC) isolated from dairy cattle in São Paulo State, Brazil. Vet. Microbiol., n.105, p.29-36, 2005.

KARMALI, M.A. Infection by verocytotoxinproducing Escherichia coli.Clin. Microbiol. Rev., v.2, p.15-38, 1989.

KONEMAN, E.W.; WILLIAM, M.J.; SCHRECKENBERGER, P.C. et al. Diagnóstico Microbiológico: texto e atlas colorido. 6.ed. Rio de Janeiro: Guanabara Koogan, 2008. 1565p.

KONOWALCHUK, J.; SPEIRS, J.I.; STAVRIC, S. Vero response to a cytotoxin of Escherichia coli.Infect. Immun., v.18, p.775-779, 1977.

LEFEBVRE, B.; DIARRA, M.S.; VINCENT, C. et al. Relative cytotoxicity of Escherichia coli O157:H7 isolates from beef cattle and humans. Foodborne Pathog. Dis., v.6, p.357-364, 2009.

LEOMIL, L.; AIDAR-UGRINOVICH, L.; GUTH, B.E.C. et al. Frequency of Shiga toxinproducing Escherichia coli (STEC) isolates among diarrheic and non-diarrheic calves in Brazil. Vet. Microbiol., v.97, p.103-109, 2003.

MENRATH, A.; WIELER, L.H.; HEIDEMANNS, K. et al. Shiga toxin producing Escherichia coli: identification of non-O157:H7-Super-Shedding cows and related risk factors. Gut Pathogens, v.2, p.1-9, 2010.
MOON, H.W. Pathogenesis of enteric diseases caused by Escherichia coli. Adv. Vet. Sci. Comp. Med., v.18, p.179-208, 1974.

MOREIRA, C.N.; PEREIRA, M.A.; BROD, C.S.et al.Shiga toxin-producing Escherichia coli (STEC) isolated from healthy dairy cattle in southern Brazil. Vet. Microbiol., v.93, p.179-183, 2003.

OJO, O.E.; AJUWAPE, A.T.; OTESILE, E.B. et al. Potentially zoonotic shiga toxin-producing Escherichia coliserogroups in the faeces and meat of food-producing animals in Ibadan, Nigeria. Int. J. Food Microbiol., v.142, p.214221,2010 .

OSEK, J. Rapid and specific identification of Shiga toxin-producing Escherichia coli in faeces by multiplex PCR. Lett. Appl. Microbiol., v.34, p.304-310, 2002.

PATON, A.W.; PATON, J.C. Detection and characterization of shiga toxigenic Escherichia coli by using multiplex PCR assays for st 1 , st 2 , $e a e A$, enterohemorrhagicE. colihlyA, rfbO111 and rfbO157. J. Clin. Microbiol., v.36, p.598602,1998 .

PATON, A.W.; WOODROW, M.C.; DOYLE, R.M. et al. Molecular characterization of a Shiga toxigenic Escherichia coli O113:H21 strain lacking eae responsible for a cluster of cases of hemolytic-uremic syndrome. J. Clin. Microbiol., v.37, p.3357-3361, 1999.

SHAW, D.J.; JENKINS, C.; PEARCE, M.C. et al.Shedding patterns of verocytotoxin-producing Escherichia coli strains in a cohort of calves and their dams on a Scottish beef farm.Appl. Environ. Microbiol., v.70, p.7456-7465, 2004.

STROCKBINE， N.A.; MARQUES， L.R.M.; NEWLAND, J.W. et al. Two toxin-converting phages from Escherichia coli O157:H7 strain 933 encode antigenically distinct toxins with similar biologic activities. Infect. Immun., v.53, p.135-140, 1986.

ZWEIFEL, C.; SCHUMACHER, S.; BLANCO, $\mathrm{M}$. et al. Phenotypic and genotypic characteristics of non-O157 Shiga toxinproducing Escherichia coli (STEC) from Swiss cattle. Vet. Microbiol.,v.105, p.37-45, 2005. 